\title{
PALYNOLOGICAL, PHYSICO-CHEMICAL AND BIOLOGICALLY ACTIVE SUBSTANCES PROFILE IN SOME TYPES OF HONEY IN THE REPUBLIC OF MOLDOVA
}

\author{
Aurica Chirsanova*, ORCID ID: 0000-0002-1172-9900, \\ Tatiana Capcanari, ORCID ID: 0000-0002-0056-5939, \\ Alina Boistean, ORCID ID: 0000-0002-5374-5853
}

Technical University of Moldova, 168 Stefan cel Mare Blvd ., MD-2004, Chișinău, Republic of Moldova

*Corresponding author: Aurica Chirsanova, aurica.chirsanova@toap.utm.md

Received: 07. 10. 2021

Accepted: 08. 28. 2021

\begin{abstract}
Three types of monofloral honey (rapeseed honey, buckwheat and lavender) from the Republic of Moldova were analyzed. The results of the palynological analysis showed that the samples had a dominant type of pollen (at least $45 \%$ ). In the case of lavender honey, the pollen of the plant Lavandula angustifolia is present in an average value of 74.83 \pm 0.3 ; in rapeseed honey - Brassica napus and for buckwheat honey -Fagopyrum esculentum in average values as follows: $56.07 \pm 0.3$ and $68.08 \pm 0.2 \%$ respectively. The study of the content of biologically active substances showed that buckwheat honey is the richest in polyphenols ( $9.00 \pm 0.11 \mathrm{mg}$ gallic acid / kg) and carotenoids (4.24 $\pm 0.57 \mathrm{mg}$ BcarotE / kg), and maximum content of flavonoids is in rapeseed honey $(4.52 \pm 0.28 \mathrm{mg}$ catechin $/ \mathrm{kg})$. Thus, the obtained results confirm that the honey from the Republic of Moldova falls within the limits recommended by the international regulation assuming adequate working conditions, handling, collection and storage of honey by beekeepers from the Republic of Moldova.
\end{abstract}

Keywords: honey, palynological analysis, physico-chemical properties, biologically active substances.

\section{Introduction}

\section{The importance of beekeeping}

For many years, honey was the only sweetener available, being an important food for Homo Sapiens since its inception [1], but the relationship between bees and human began in the Stone Age. During the evolution of mankind, bee honey was a valuable food product. Very often it was a commercial currency and had a high price. Some taxes could be paid with bee honey [2]. There has always been a strong connection between humans and bees. This relationship is largely based on the fact that $80 \%$ of the world's plants are pollinated by bees [3]. Beekeeping is becoming a key occupation for generating additional income for rural people, especially in developing countries [4]. It does not take a lot of capital to practice 
beekeeping. This form of activity has a low maintenance and generates good income in a short period of time. [5, 6].

Beekeeping has the unique ability to contribute to the achievement of 15 of the 17 goals mentioned by the United Nations Sustainable Development Goals and among the most important goals are: eradication, poverty and hunger, contributing to maintaining health and a healthy lifestyle, achieving sustainable production and consumption systems, developing entrepreneurship, gender equality and others [7].

\section{Characteristic of the beekeeping sector in the Republic of Moldova}

Agriculture is one of the vectors of image of the Republic of Moldova and is a strategic sector of national importance, whose operation takes place under the social, climatic and economic impact, but also other specific factors, which determine the uniqueness of this sphere $[8,9]$.

In the context of its aspirations to become a member of the European Union, reforms in the agri-food sector must comply with EU regulations, which will allow it to adapt to the demands of international markets, especially in the field of food safety, security and authenticity. In this context, the report entitled "Evaluation of the National Food Control System of the Republic of Moldova [10] presented by the FAO [11] shows that in the agrifood sector, it is necessary to strengthen relations between producers, processors, exporters, representatives of academia and institutes. research to ensure the sustainability and authentication of food.

Among the agricultural crops that provide bees with nectar and pollen are sunflower, rapeseed and buckwheat, which are grown on large areas, so bees participate in their pollination by influencing the quality and quantity of seeds obtained.

The surfaces of the fruit plantations from the agricultural enterprises and the peasant households represent 44,323 ha, and for their pollination approximately 132,969 bee families are necessary.

In the Republic of Moldova during the years 2008 - 2017 was reported a slight increase in the number of bee families, their number ranging from 98.3 thousand in 2008 to 148.1 thousand pieces, in 2017, 1.51 times higher. Currently, over 5,250 apiaries have passports.

\section{Honey on the market of the Republic of Moldova}

The cost of producing one kilogram of honey in the Republic of Moldova depends largely on the amount of honey obtained, which is closely related to climatic conditions and is in the range of 1.65 - 1.80 US dollars in the case of a "normal" year.

According to a study conducted by the Organization for Investment Attraction and Export Promotion of Moldova in 2012, the annual costs of operating a hive are around US \$ 58 . The honey-commodity productivity of bee families is around $24 \mathrm{~kg} /$ season, being closely dependent on the annual climatic conditions [12].

Compared to neighboring countries, the volume of exports to the European Union of the Republic of Moldova is relatively small.

At the same time, the quality of local honey is high (especially the glucose / fructose ratio), although its price is not highly competitive compared to the main competitors Ukraine, China and Argentina. Thus, for the Republic of Moldova the opportunity to access the market is the sale of quality honey, including organic [13]. 


\section{Honey export from Republic of Moldova}

Maximum 15\% of the total volume of honey produced in the Republic of Moldova is consumed locally. The main distribution channel consists of friends, neighbors and relatives of beekeepers.

The price of honey sold to individuals is twice as high as the wholesale price offered by large intermediaries. However, low wholesale prices as well as high production costs stop investment in the honey production sector.

The remaining about $85 \%$ of production volume is currently exported. For our country, the main market is that of the European Union, which assimilates over $90 \%$ of exported honey, and in 2015 the ratio was $98 \%$. The main destinations of local honey are Italy, Germany, France, Slovakia, as well as some smaller, but still considerable markets such as Romania, Poland, Denmark, etc. (Table 1) [14].

Tabel 1

Export of honey from the Republic of Moldova in tons and thousands of US dollars [9]

\begin{tabular}{|c|c|c|c|c|c|c|c|c|}
\hline \multirow[t]{2}{*}{ Destination } & \multirow[b]{2}{*}{ 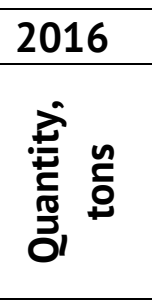 } & \multicolumn{2}{|c|}{2017} & \multicolumn{2}{|r|}{2018} & \multicolumn{3}{|c|}{2019} \\
\hline & & 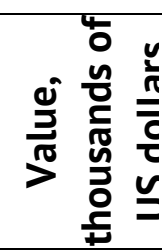 & 竎 & 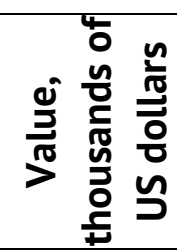 & 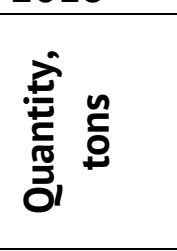 & 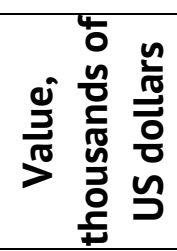 & 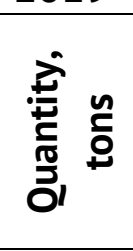 & 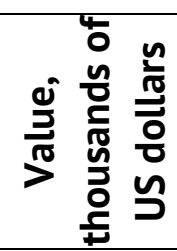 \\
\hline Total & 3160,3 & $\begin{array}{l}8 \\
844,7\end{array}$ & $\begin{array}{l}5 \\
010,5\end{array}$ & 14049,9 & 94123,5 & 11740,8 & $\begin{array}{l}3 \\
888,9\end{array}$ & 11584,5 \\
\hline \multicolumn{9}{|c|}{ Including EU countries: } \\
\hline Italy & 632,5 & $\begin{array}{l}1 \\
887,0\end{array}$ & 867,7 & 2680,4 & 784,2 & 2523,5 & 923,8 & 3055,6 \\
\hline Germany & 535,9 & $\begin{array}{l}1 \\
370,1\end{array}$ & 445,3 & 1176,4 & 424,8 & 1090,5 & 264,7 & 705,0 \\
\hline France & 336,0 & $\begin{array}{l}1 \\
106,8\end{array}$ & 756,0 & 2205,5 & 546,0 & 1601,7 & 525,0 & 1651,0 \\
\hline Slovakia & 251,1 & 700,5 & 468,9 & 1439,7 & 471,8 & 1360,2 & 660,1 & 1794,9 \\
\hline Romania & 822,5 & $\begin{array}{l}2 \\
304,9\end{array}$ & $\begin{array}{l}1 \\
490,9\end{array}$ & 3928,1 & 619,9 & 1671,3 & 645,9 & 1893,5 \\
\hline Poland & 46,9 & 122,2 & 181,9 & 487,1 & 442,7 & 1391,7 & 129,0 & 541,0 \\
\hline Danemark & 60,3 & 140,4 & - & - & - & - & - & - \\
\hline Austria & 121,2 & 288,5 & 80,0 & 153,1 & - & - & 21,0 & 55,5 \\
\hline Belgium & 102,3 & 226,3 & - & - & - & - & 21,0 & 53,2 \\
\hline \multicolumn{9}{|c|}{ Other countries of the world: } \\
\hline Macedonia & 126,0 & 319,5 & 168,0 & 417,1 & 252,0 & 604,6 & 63,0 & 151,3 \\
\hline
\end{tabular}

The Republic of Moldova exported a record amount of honey worth $\$ 14.0$ million in 2017. Exports increased from 245 tons in 2006 to 5010 tons in 2017 . Honey is the only animal product that is exported to the EU, as it meets import requirements from EU third countries for products of animal origin. To achieve this, it is necessary to demonstrate that the country has a "residue monitoring mechanism" established for the analysis of honey for residues of antibiotics, sulphonamides, pesticides and heavy metals, as defined in the veterinary standard on measures for the supervision and control of certain substances and their residues in live 
animals and their products, as well as of residues of veterinary medicinal products in products of animal origin, approved by Government Decision no. 298/2011 (harmonized with the provisions of Council Directive 96/23 / EC of 29 April 1996 on measures to monitor certain substances and their residues in live animals and animal products (EU OJ of 23 May 1996, L 125 , p. 10).

\section{Adulteration and physico-chemical characteristics of honey}

Adulteration of honey is generally a major concern of consumers but also of honest producers. Honey adulteration has been a challenge for analysis for decades. Adulteration has been used to increase economic benefits by adding honey or sugars at reduced prices during production or processing. In addition, these food adulterants are often unique, so they avoid being detected by routine tests [15]. In previous studies, various methods have been used to test the authenticity of honey, such as near-infrared spectroscopy, anion exchange chromatography coupled with pulsed amperometric detection [16], nuclear magnetic resonance [17, 18] high performance liquid chromatography [19, 20] Fourier transform infrared spectroscopy [21] and the $13 \mathrm{C} / 12 \mathrm{C}$ isotope ratio analysis method $[22,23]$.

The composition of bee honey represents is a natural, very complex mixture containing various chemical compounds. These compounds give bees honey important biological properties, such as the ability to promote wound healing [24], antimicrobial and anti-inflammatory capacity [25]. Antioxidant capacity is associated with its content of antioxidant compounds, such as polyphenols [26].

Its antimicrobial properties are associated, in particular, with the osmotic properties of bee honey, as well as with the presence of hydrogen peroxide and other minor compounds without peroxide, such as polyphenols and a special protein known as defensin-1 [27, 28].

The purpose of this study was to demonstrate the authenticity of honey by palynological analysis and to highlight the physico-chemical composition and biologically active compounds of some types of honey in the Republic of Moldova.

\section{Materials and methods}

This study was conducted using honey declared by beekeepers to be buckwheat, rapeseed and lavender purchased from local producers in Chisinau. The research was conducted between November 2020 and January 2021 in the laboratories of the Department of Food and Nutrition of the Faculty of Food Technology of the Technical University of Moldova. During the research, the honey samples were kept in laboratory conditions, packed in sealed glass jars at a temperature of $21 \pm 2^{\circ} \mathrm{C}$.

\section{Palynological analysis}

It was performed by microscopic analysis according to the method of Lutier and Vaissière (1993) [29,30].

\section{Humidity}

Mass fraction of water was determined using Honey humidity refractometer ATAGO 4422 PAL-22S, 12.0 to $30.0 \%$, acc. $\pm 0.2 \%$.

\section{Determination of $\mathrm{pH}$}

The $\mathrm{pH}$ of the samples was measured potentiometrically at $20^{\circ} \mathrm{C}$. The $\mathrm{pH}$ meter was used (HANNA HI9124, Germany). The research solutions were prepared by dissolving $1 \mathrm{~g}$ of bee honey in $10 \mathrm{ml}$ of distilled water. 


\section{Determination of Acidity}

Free acidity was determined by titrimetric method. It is based on the titration of the honey sample diluted with water, with $0.1 \mathrm{n} \mathrm{NaOH}$ in the presence of phenolphthalein as indicator.

\section{Diastase index}

The basis of this method is the determination of amylase activity. The diastase index is defined as the number of milliliters of starch solution $(1 \%)$ which has been converted to dextrin for one hour at temperature $45^{\circ} \mathrm{C}$ at the optimum $\mathrm{pH}$ of amylase containing $1 \mathrm{~g}$ of sample.

\section{Hydroxymethylfurfural content}

The Fiehe reaction is based on the fact that the hydroxymethylfurfural forms with the resorcinol, in hydrochloric acid medium, a complex colored in red, whose color intensity is proportional to the quantity of the respective compound. When the Fiehe reaction is positive, the honey is considered suspicious and the deconfirmation test is further performed by determining the hydroxymethylfurfural content.

\section{Determination of total sugar content}

The honey bees were dissolved in distilled water to obtain a $25 \%(\mathrm{w} / \mathrm{v})$ solution. The total sugar content of the honey samples was determined using the refractometric method (portable refractometer ATAGO PAL-22S, Japan). The sucrose content was expressed in $\mathrm{g} / \mathrm{ml}$ of honey.

\section{Reducing sugar}

To determine the reducing sugar (by the Elser method) it was taken into account that glucose and fructose, in the free state, have the ability to reduce copper sulfate in an alkaline and hot environment, which it transforms into copper oxide. The amount of copper oxide that is formed under specific working conditions is proportional to the concentration of the two reducing sugars in the solution to be researched.

\section{Sucrose content}

For the determination of sucrose (by Elser method) the direct reducing sugar was determined before and after inversion (acid hydrolysis), and from the difference sucrose is calculated.

\section{Determination of flavonoids}

The total flavonoid content was determined using the colorimetric method [31]. Sample of $1 \mathrm{ml}$ bee honey was mixed with $4 \mathrm{ml}$ of distilled water. $0.3 \mathrm{ml}$ of NaNO2 (5\%, w / v) was added. After $5 \mathrm{~min}, 0.3 \mathrm{~mL}$ of $\mathrm{AlCl} 3(10 \% \mathrm{w} / \mathrm{v})$ was added. This was followed by the addition of $2 \mathrm{~mL}$ of $\mathrm{NaOH}(1 \mathrm{~N}) 6$. The volume of the mixture was adjusted to $10 \mathrm{ml}$ by the addition of $2.4 \mathrm{ml}$ of distilled water. The composition was stirred (VORTEX V-1 plus, BioSan) to ensure a homogeneous mixture. The absorbance was read at $510 \mathrm{~nm}$. Results were expressed as mg equivalent of catechin (CEQ) per kg of honey.

\section{Determination of total polyphenol contents}

Total polyphenol contents were determined using the Folin-Ciocalteu colorimetric method [40]. The honey sample solution $(0.1 \mathrm{~mL})$ was mixed with Folin-Ciocalteu reagent $(0.5 \mathrm{~mL})$ and $\mathrm{Na}_{2} \mathrm{CO}_{3}(0.4 \mathrm{~mL}$ of $7.5 \%)$, and the absorbance was measured at wavelength 765 $\mathrm{nm}$ after $10 \mathrm{~min}$ at temperature $37^{\circ} \mathrm{C}$. Total polyphenol contents were expressed as $\mathrm{mg} \mathrm{GAE}$ gallic acid equivalents $/ 100 \mathrm{~g}$ honey. 


\section{Determination of total carotenoid content}

The total carotenoid content was determined spectrophotometrically a previously published method [32]. The absorbance was determined at wavelength $450 \mathrm{~nm}$. The results were expressed as $\mathrm{mg}$ of $\beta$-carotene equivalents ( $\beta$ carotE) per $\mathrm{kg}$ of honey ( $\mathrm{mg} \beta$ carotE / $\mathrm{kg}$ of honey).

\section{Statistical Analyses}

All analyzes were performed in triplicate, and the results were expressed as mean values with standard deviations (SD).

The significant differences represented by letters were obtained by a one-way analysis of variance (ANOVA) followed by Tukey's honestly significant difference (HSD) post hoc test $(p<0.05)$. Correlations were established using Pearson's correlation coefficient $(r)$ in bivariate linear correlations $(p<0.01)$. These treatments were carried out using Microsoft office Excel 2007 and SPSS v. 18.0 program.

\section{Results}

\section{Palynological analysis of honey}

One of the fundamental criteria for the quality of honey that influences its commercial value is the declaration of botanical and geographical origin.

The results of the analysis of the pollen profile of honey allow us to determine the floral origin of honey and to confirm the identity of the honey source indicated by beekeepers. The pollen grains identified and their frequency in the three types of honey analyzed are shown in Table 2.

The results of the quantitative pollen analysis showed that the samples always had a dominant pollen type (at least 45\%) and can be classified as monofloral thus confirming the name declared to the consumer as follows: buckwheat honey, rapeseed honey and lavender honey.

Monofloral status usually means the presence of pollen of the same type in the amount of more than $45 \%$ of the total pollen content in the sample.

We notice that in the analyzed samples the content of a single type of pollen is much higher than: the minimum figure in the case of lavender honey is present the pollen of the plant Lavandula angustifolia in average value of $74.83 \pm 0.3$; for rapeseed honey - Brassica napus pollen and for buckwheat honey the dominant pollen Fagopyrum esculentum is present in average values as follows: $56.07 \pm 0.3$ and $68.08 \pm 0.2 \%$.

Table 2

Palynological characteristic

\begin{tabular}{|c|c|c|c|c|c|c|}
\hline \multirow[b]{2}{*}{$\begin{array}{c}\text { The type of } \\
\text { honey } \\
\text { declared }\end{array}$} & \multicolumn{5}{|c|}{ Pollen type } & \multirow{2}{*}{$\begin{array}{c}\text { Examples } \\
\text { of images } \\
\text { of } \\
\text { dominant } \\
\text { pollen }\end{array}$} \\
\hline & $\begin{array}{c}\text { Sunflower } \\
\text { (Helianthus } \\
\text { annuus) }\end{array}$ & $\begin{array}{l}\text { Acacia } \\
\text { (Robinia } \\
\text { pseudo } \\
\text { acacia) }\end{array}$ & $\begin{array}{c}\text { Rapeseed } \\
\text { (Brassica } \\
\text { napus) }\end{array}$ & $\begin{array}{c}\text { Buckwheat } \\
\text { (Fagopy } \\
\text { rume } \\
\text { sculentum) }\end{array}$ & $\begin{array}{l}\text { Lavender } \\
\text { (Lavandula } \\
\text { angustifolia) }\end{array}$ & \\
\hline
\end{tabular}

\section{Buckwheat}

$(\mathrm{n}=5)$

\begin{tabular}{lllll} 
Presence & $3 \mathrm{~S}, 2 \mathrm{IM}$ & $2 \mathrm{IM}, 3 \mathrm{~S}$ & $5 \mathrm{PM}$ & $5 \mathrm{M}$ \\
$\%$ & $53.5,46.7$ & $13.3,86.7$ & 100 & 100 \\
average \pm SD & $22,4 \pm 0,1$ & $8,47 \pm 0,3$ & $68,08 \pm 0,2$ & $1,05 \pm 0,1$ \\
\hline
\end{tabular}


Continuation Table 2

\begin{tabular}{|c|c|c|c|c|c|c|}
\hline $\begin{array}{l}\text { Rapeseed } \\
(n=5)\end{array}$ & & & & & & \\
\hline Presence & $3 \mathrm{IM}, 2 \mathrm{M}$ & $2 \mathrm{IM}, 3 \mathrm{M}$ & 5 PM & & & \\
\hline$\%$ & $53.5,46.7$ & $13.3,86.7$ & 100 & & & \\
\hline average $\pm S D$ & $24,31 \pm 0,3$ & $19,62 \pm 0,2$ & $56,07 \pm 0,3$ & & & \\
\hline $\begin{array}{l}\text { Lavender } \\
(\mathrm{n}=5)\end{array}$ & & & & & & \\
\hline Presence & $2 \mathrm{IM}, 3 \mathrm{M}$ & $2 M$ & & $1 \mathrm{M}$ & 5 PM & \\
\hline$\%$ & $13.3,86.7$ & 100 & & 100 & 100 & \\
\hline average $\pm S D$ & $13,01 \pm 0,1$ & $10,11 \pm 0,1$ & & $2,05 \pm 0,2$ & $74,83 \pm 0,3$ & \\
\hline
\end{tabular}

Note: predominant pollen (>45\%) - P; secondary pollen, (16-45\%)-S; important minor pollen, (3-15\%)-IM; minor pollen, $(1-3 \%)-M$.

$n=$ sample size

It should be noted that the pollen Helianthus annuus and Robinia pseudoacacia is present in all three types of honey analyzed, either as secondary pollen, as important minor pollen or as minor pollen. At the same time, the variations of the nectar content, together with other factors such as climatic and geographical conditions, soil type, practices applied by beekeepers and others, contribute to the existence of different types of honey and imprint their botanical origin [33 - 35].

\section{Physico-chemical characteristics of the samples}

Table 3 presents the physico-chemical parameters of the types of honey from the Republic of Moldova under study. Depending on the borane origin of honey, significant differences were observed in some of the physico-chemical parameters $(p<0.05)$.

The moisture content of Apis mellifera honey is well defined by international quality standards [36]. A high moisture content in honey can affect both its quality and its biological activity and organoleptic properties [37]. According to the results obtained, all honey samples examined were within acceptable limits. It is known that the moisture content of honey also depends on the ecological and geographical conditions, the maintenance of the apiary and the storage of the finished product $[38,39]$. Thus, the results obtained suggest adequate working conditions, processing, collection and storage of honey by beekeepers from the Republic of Moldova.

Table 3

Physico-chemical parameters

\begin{tabular}{lllll}
\hline & $\begin{array}{c}\text { Rapeseed } \\
(\mathrm{n}=5)\end{array}$ & $\begin{array}{c}\text { Buckwheat } \\
(\mathrm{n}=5)\end{array}$ & $\begin{array}{c}\text { Lavender } \\
(\mathrm{n}=5)\end{array}$ & Mean \\
\hline Humidity \% & $22,0 \pm 0,01$ & $15,60 \pm 0,02$ & $17,00 \pm 0,01$ & $18,2 \pm 0,03$ \\
\hline Ash, \% & $0,9 \pm 0,03$ & $1,1 \pm 0,06$ & $0,17 \pm 0,02$ & $0,72 \pm 0,04$ \\
\hline $\mathbf{p H}$ & $3,32 \pm 0,10$ & $3,48 \pm 0,11$ & $3,68 \pm 0,04$ & $3,49 \pm 0,08$ \\
\hline Total acidity, $\mathbf{c m}^{3}$ & $9,98 \pm 0,03$ & $22,09 \pm 0,01$ & $7,11 \pm 0,01$ & $13,06 \pm 0,17$ \\
\hline $\begin{array}{l}\text { Hydroxymethylfurfural } \\
\text { (mg/kg of honey) }\end{array}$ & $70,81 \pm 0,06$ & $13,78 \pm 0,04$ & $27,16 \pm 0,03$ & $37,26 \pm 0,04$ \\
\hline Diastase index $\left(\mathbf{c m}^{\mathbf{3}} / \mathbf{g}\right)$ & $22,13 \pm 0,01$ & $19,12 \pm 0,03$ & $14,11 \pm 0,02$ & $28,45 \pm 0,02$ \\
\hline
\end{tabular}


Continuation Table 3

Water insoluble matter:

\begin{tabular}{llll}
\hline Cereal flour & Lack & Lack & Lack \\
\hline Gelatin & Lack & Lack & Lack \\
\hline Starch & Lack & Lack & Lack
\end{tabular}

It is known that honey is acidic nature. The values of $\mathrm{pH}$ obtained in the honey samples varied between 3.32 and 3.68 and fall within the previously reported values [40, 41].

Hydroxymethylfurfural (HMF) is used as an indicator of honey freshness [42]. In fresh honey, HMF may be absent or in small amounts, while high levels of HMF (> $80 \mathrm{mg} / \mathrm{kg}$ ) indicate that honey may have been stored and handled in inappropriate conditions, such as abuse of high temperatures [43]. In the three types of honey analyzed, the HMF content was $13.78 \pm 0.04 \mathrm{mg} / \mathrm{kg}$ for buckwheat honey, $27.16 \pm 0.03 \mathrm{mg} / \mathrm{kg}$ for lavender honey and 70.81 $\pm 0.06 \mathrm{mg} / \mathrm{kg}$ for rapeseed honey. According to the presented results, all samples from the three types of monofloral honey analyzed were within the recommended limits and were in accordance with international regulations for this type of honey.

The diastatic index ranges from $14.11 \pm 0.02$ for lavender honey to $22.13 \pm 0.01$ for rapeseed honey. At the same time for buckwheat, this index is $19.12 \pm 0.03$. The mean for the samples under study was $28.45 \pm 0.02$. It should be noted that water-insoluble substances (cereal flour, gelatin or starch) were not detected. The presence of impurities in the end product of beekeeping can be introduced during preparation, process of centrifugation or process of packaging. An improper honey filtering process can be a source of insoluble substances in the finished product. Therefore, during this process, honey passes through several sieves [42]. No water-insoluble substances were detected in the analyzed honey. At the same time, the water-insoluble ingredients (at temperature $+80^{\circ} \mathrm{C}$ ), present in honey, constitute the residue left after filtering the honey solution. High-quality honey should not contain more than $0.1 \mathrm{~g} / 100 \mathrm{~g}$ of insoluble ingredients, except for pressed honey (norm: not more than $0.5 \mathrm{~g} / 100 \mathrm{~g}$ ) [44].

\section{Total Sugar Content}

None of the samples examined exceeded the maximum sugar content set for the total sugar content (Table 4) by the European Community Directive [44]

Means obtained are compared by using One-way ANOVA. In column, values with different superscripts letters indicate significant differences $(p<0.05)$

Table 4

Total Sugar Content

\begin{tabular}{lcccc}
\hline & $\begin{array}{c}\text { Rapeseed } \\
(\mathrm{n}=5)\end{array}$ & $\begin{array}{c}\text { Buck wheat } \\
(\mathrm{n}=5)\end{array}$ & $\begin{array}{c}\text { Lavender } \\
(\mathrm{n}=5)\end{array}$ & Mean \\
\hline $\begin{array}{l}\text { Total sugar } \\
\text { content mean } \pm \\
\text { SD\% }(\mathbf{g} / \mathbf{m L})\end{array}$ & $69,82 \pm 1,04^{\mathrm{a}}$ & $66,61 \pm 0,42^{\mathrm{b}}$ & $61,09 \pm 0,40^{\mathrm{a}}$ & $65,84 \pm 0,62$ \\
\hline $\begin{array}{l}\text { Reducing sugar } \\
\text { mean } \pm \text { SD (\%) } \\
\mathbf{g} / \mathbf{g}\end{array}$ & $61,12 \pm 0,61^{\mathrm{a}}$ & $62,14 \pm 0,51^{\mathrm{b}}$ & $67,07 \pm 0,47^{\mathrm{a}}$ & $62,44 \pm 0,53$ \\
\hline $\begin{array}{l}\text { Sucrose mean } \pm \\
\text { SD (\%) }\end{array}$ & $2,32 \pm 0,61$ & $1,92 \pm 0,76$ & $2,52 \pm 0,21$ & $2,25 \pm 0,53$ \\
\hline
\end{tabular}


From the above we can see that the total sugar content is the highest in the samples of rapeseed honey and is $69.82 \pm 1.04 \mathrm{~g} / \mathrm{ml}$, followed by buckwheat honey with a content of $66.61 \pm 0.42 \mathrm{~g} / \mathrm{ml}$ and then lavender honey with $61.09 \pm 0.40 \mathrm{~g} / \mathrm{ml}$. Thus, the average total sugar content in the 15 samples analyzed was $65.84 \pm 0.62 \mathrm{~g} / \mathrm{ml}$.

\section{Bioactive compounds}

Polyphenols, flavonoids and carotenoids were present in all samples subjected to the study (table 5).

Table 5

Content of bioactive substances

\begin{tabular}{lcccc}
\hline & $\begin{array}{c}\text { Rapeseed } \\
(\mathrm{n}=5)\end{array}$ & $\begin{array}{c}\text { Buckwheat } \\
(\mathrm{n}=5)\end{array}$ & $\begin{array}{c}\text { Lavender } \\
(\mathrm{n}=5)\end{array}$ & Mean \\
\hline $\begin{array}{l}\text { Polyphenols } \\
\text { mean } \pm \text { SD } \\
(\text { mg gallic acid/kg) }\end{array}$ & $6,20 \pm 0,17^{\mathrm{a}}$ & $9,00 \pm 0,11^{\mathrm{a}}$ & $5,20 \pm 0,08^{\mathrm{b}}$ & $6,8 \pm 0,12$ \\
\hline $\begin{array}{l}\text { Flavonoids } \\
\text { mean } \pm \text { SD } \\
(\text { mg catechin/kg) }\end{array}$ & $4,52 \pm 0,28^{\mathrm{a}}$ & $2,09 \pm 0,14^{\mathrm{b}}$ & $0,81 \pm 0,19^{\mathrm{c}}$ & $2,47 \pm 0,21$ \\
\hline $\begin{array}{l}\text { Carotenoids } \\
\text { mean } \pm \text { SD } \\
(\text { mg } \beta \text { carotE/kg) }\end{array}$ & $2,60 \pm 0,23^{\mathrm{a}}$ & $4,24 \pm 0,57^{\mathrm{b}}$ & $0,70 \pm 0,31^{\mathrm{c}}$ & $2,51 \pm 0,37$ \\
\hline
\end{tabular}

Means obtained are compared by using One-way ANOVA. In column, values with different superscripts letters indicate significant differences $(p<0.05)$

The average polyphenol content was $6.8 \pm 0.12$ (mg gallic acid / kg), and for buckwheat honey the amount of $9.00 \pm 0.11$ ( $\mathrm{mg}$ gallic acid / kg) was identified. The average content of flavonoids was $2.47 \pm 0.21$ (mg catechin / $\mathrm{kg}$ ), and for rapeseed honey it was the highest content $-4.52 \pm 0.28$ (mg catechin / kg). Phenolic acid (non-flavonoids) and flavonoids are responsible for inhibiting oxidation and destroying free radicals. Them identification and classification are based on their chemical structures, which consist of one or more hydroxyl groups which are fused to a closed ring structure and that way produce an aromatic ring containing 6 carbon atoms with hydrogen atoms [45]. The color tone of honey is influenced by both physical and chemical indicators and the botanical origin of honey, which contributes to the diversity of its assortment. Such compounds as polyphenols, carotenes and minerals also affect color of honey [46, 47]. Flavonoids are considered substances with a major effect on chromatic parameters $[48,49]$. While collecting nectar, bees transfer these biologically active compounds from plants to honey [50].

\section{Conclusions}

This study showed following the palynological analysis that the three types of honey: rapeseed honey, buckwheat and lavender can be classified as monofloral thus confirming the name declared to the consumer. At the same time, the identification of the botanical origin of honey could be a useful tool for differentiating the product, in order to guarantee a better qualitative characterization and its traceability in itself.

It was demonstrated that the physico-chemical properties of the samples under study were within the recommended limits and were in accordance with international regulations for these parameters. The content of biologically active substances: polyphenols, flavonoids 
and carotenoids in the studied samples is of great importance, therefore, these types of product can be used as a natural food ingredient, as well as a rich source of antioxidants in the diet of the population.

Acknowledgments: The results of the research presented were carried out within the project «Développement durable de l'apiculture: enjeux économiques, écologiques, de développement rural et de santé publique», which took place during the years 2019-2021. The project was funded by the "Agence Universitaire de la Francophonie en Europe Centrale et Orientale".

\section{References}

1. Suvro S. "Honey- The natural sweetener become a promising alternative therapeutic: a review." In:South Indian Journal of Biological Sciences, 2015, 1, pp. 103 - 114.

2. Crane E. A Short History of Knowledge about Honey Bees (Apis) up to 1800. In: Bee World, 2004, 85 (1), pp. 6 - 11.

Disponibil: https://doi.org/10.1080/0005772X.2004.11099604.

3. Baker T.F. Bees and Beekeeping, Bloomsbury Publishing, 2021, pp. 94.

4. Hinton J., Schouten C., Austin A., Lloyd D. An Overview of Rural Development and Small-Scale Beekeeping in Fiji. In: Bee World, 2020, 97 (2), pp. 39 - 44.

Disponibil: https://doi.org/10.1080/0005772X.2019.1698104.

5. Altunel T., Olmez B. Beekeeping as a Rural Development Alternative in Turkish Northwest. In: Appl. Ecol. Environ. Res. 2019, 17 (3), pp. 6017 - 6029. Disponibil: https://doi.org/10.15666/aeer/1703_60176029.

6. Pocol Cristina Bianca, Sedik Peter,Brumă Ioan Sebastian, Amuza Antonio, Chirsanova Aurica. Organic beekeeping practices in Romania: Status and perspectives towards a sustainable development. In: Agriculture (Switzerland). 2021, nr. 4(11), pp. 1 - 18. ISSN 2077-0472.10.3390/agriculture11040281

Disponibil: https://doi.org/10.3390/agriculture11040281

7. Patel V., Pauli N., Biggs E., Barbour L., Boruff B. Why Bees Are Critical for Achieving Sustainable Development. In: Ambio, 2021, 50 (1), pp. 49 - 59.

Disponibil: https://doi.org/10.1007/s13280-020-01333-9.

8. Asociația Exportatorilor de Produse Apicole din Moldova (AEPAM)

Disponibil: https://honeymoldova.md/about-hea/

9. Eremia N., Modvala S., Naraevscaia I. Dinamica efectivului familiilor de albine şi a suprafeţelor pomilor fructiferi în Republica Moldova, Universitatea Agrară de Stat din Moldova, CZU 638.124(478)

Disponibil: http://particip.gov.md/proiectview.php?l=ro\&idd=4687\#?l=ro\&idc=507

10. Chirsanova Aurica, Reșitca Vladislav. Factori de bază ce influenţează politicile alimentare şi nutriţionale la nivel internaţional. Meredian ingineresc. Univestitatea Tehnică a Moldovei. Nr. 3, 2013, ISSN 1683-853X. p.86-92.

Disponibil: https://ibn.idsi.md/ro/vizualizare_articol/27531

11. Chirsanova Aurica, Calcatiniuc Dumitru. The impact of food waste and ways to minimize IT. In: Journal of Social Sciences. 2021, nr. 4(1), pp. 128 - 139. ISSN 2587-3490.10.52326/jss.utm.2021.4(1).15

Disponibil: https://doi.org/10.52326/jss.utm.2021.4(1).15

12. Eremia N., Scripnic E., Modvala S., Chiriac A. Influence of temperature on nectar collection and storage in the hive during honey harvest. University of Agricultural Sciences and Veterinary Medicine lasi. 2017, pp. 40 - 44.

13. Hotărîrea guvernului Republicii Moldova, Cu privire la aprobarea Programului național de dezvoltare a apiculturii în Republica Moldova pentru anii 2021 - 2025 și a Planului de acțiuni privind implementarea acestuia pentru anii 2021-2022.

Disponibil: https://gov.md/sites/default/files/document/attachments/subiect-14.pdf

14. Chirsanova A., Capcanari T., Gîncu E. Jerusalem Artichoke (Helianthus Tuberosus) flour impact on bread quality. Journal of Engineering Science. Vol. XXVIII, no. 1, 2021, pp. 131 - 143. ISSN 2587-3474. Disponibil: https://doi.org/10.52326/jes.utm.2021.28(1).14

15. Sobrino-Gregorio L.,Vilanova S., Jaime Prohens, J., Escriche,I. Detection of honey adulteration by conventional and real-time PCR, Food Control, Volume 95, 2019, Pages 57-62, ISSN 0956-7135, https://doi.org/10.1016/j.foodcont.2018.07.037. 
16. Wang J., Xue X., Du X. Identification of Acacia Honey Adulteration with Rape Honey Using Liquid Chromatography-Electrochemical Detection and Chemometrics. In: Food Anal. Methods, 2014, 7, pp. $2003-$ 2012. Disponibil: https://doi.org/10.1007/s12161-014-9833-7

17. Song X., She D., Xin, M., Chen L., Li Y., Vander Heyden Y., Rogers K.M., Chen L. Detection of adulteration in Chinese monofloral honey using $1 \mathrm{H}$ nuclear magnetic resonance and chemometrics, In: Journal of Food Composition and Analysis, 2020, 86, 103390, ISSN 0889-1575.

Disponibil: https://doi.org/10.1016/j.jfca.2019.103390.

18. Fan, K., Zhang, M. Recent developments in the food quality detected by non-invasive nuclear magnetic resonance technology, Critical Reviews in Food Science and Nutrition, 2019, 59(14), pp.2202-2213. Disponibil: 10.1080/10408398.2018.1441124

19. Ghramh,H.A., Khan, K.A., Zubair, A., Ansari, M.J. Quality evaluation of Saudi honey harvested from the Asir province by using high-performance liquid chromatography (HPLC). In: Saudi Journal of Biological Sciences, 27(8), 2020, pp.2097-2105.

Disponibil: https://doi.org/10.1016/j.sjbs.2020.04.009.

20.Zhu Z., Zhang Y., Wang J., Li X., Wang W., Huang Z. Sugaring-out assisted liquid-liquid extraction coupled with high performance liquid chromatography-electrochemical detection for the determination of 17 phenolic compounds in honey, In: Journal of Chromatography A, 2019, 1601, pp. 104 - 114. Disponibil: https://doi.org/10.1016/j.chroma.2019.06.023.

21.Cengiz M.F., Durak M.Z. Rapid detection of sucrose adulteration in honey using Fourier transform infrared spectroscopy, In:Spectroscopy Letters, 2019, 52(5), pp. 267 - 273.

Disponibil: 10.1080/00387010.2019.1615957

22. Tosun M. Detection of adulteration in honey samples added various sugar syrups with $13 \mathrm{C} / 12 \mathrm{C}$ isotope ratio analysis method, Food Chemistry, 2013, 138(2-3), pp. 1629 - 1632.

Disponibil: https://doi.org/10.1016/j.foodchem.2012.11.068.

23. Geană E-L., Ciucure C.T., Costinel D., Ionete R.E. Evaluation of honey in terms of quality and authenticity based on the general physicochemical pattern, major sugar composition and $813 \mathrm{C}$ signature, Food Control, 2020, 109, 106919.

Disponibil: https://doi.org/10.1016/j.foodcont.2019.106919.

24.Alvarez-Suarez J.M., Giampieri F., Battino M. Honey as a source of dietary antioxidants: Structures, bioavailability and evidence of protective effects against human chronic diseases. In: Curr. Med. Chem., 2013, 20, pp. $621-638$.

25. Cooper, R. Honey for wound care in the 21st century. In: J. Wound Care, 2016, 25, pp. $544-552$.

26. Cianciosi D., Forbes-Hernández T.Y., Ansary J., Gil E., Amici A., Bompadre S., Simal-Gandara J., Giampieri F., Battino M. Phenolic compounds from Mediterranean foods as nutraceutical tools for the prevention of cancer: The effect of honey polyphenols on colorectal cancer stem-like cells from spheroids, In: Food Chemistry, 325, 2020, 126881.

Disponibil: https://doi.org/10.1016/j.foodchem.2020.126881.

27. Santos-Buelga C., González-Paramás A.M. Chemical Composition of Honey. In Bee Products-Chemical and Biological Properties. In: Springer International Publishing: Cham, Switzerland, 2017, pp. 43 - 82.

28.Vrabie, V., Yazlovitska, L., Ciochină, V., Rotaru, S. Comparative content of free aminoacids in pollen and honey. In: Buletin Ştiinţific. Revista de Etnografie, Ştiinţ̧ele Naturii şi Muzeologie (Serie Nouă), 2019, 30(43), pp. 71 - 78.

29. Chirsanova A., Covaliov E., Capcanari T., Suhodol N., Deseatnicova O., Boistean A., Resitca V., Sturza R. Consumer behavior related to salt intake in the Republic of Moldova. Journal of Social Sciences. Vol. III, no. 4, 2020, pp. 101 - 110. DOI: 10.5281/zenodo.4296387 CZU 366:613.2:664.41(478). Disponibil: https://jss.utm.md/wp-content/uploads/sites/21/2021/01/JSS-4-2020-pp_101-110.pdf

30. Palynological analysis of honey, value and quality characteristics

Disponibil: $\quad$ http://honey-land.ru/nauka-o-pchelakh/palinologicheskiy-analiz-otsenki-botanicheskogoproiskhozhdeniya-meda.php

31.Zhishen J., Mengcheng T., Jianming W. The determination of flavonoid contents in mulberry and their scavenging effects on superoxide radicals. In: Food Chem., 1999, 64, pp. 555 - 559.

32. Ferreira I.C.F.R., Aires E., Barreira J.C.M., Estevinho L.M. Antioxidant activity of Portuguese honey samples: Different contributions of the entire honey and phenolic extract. In: Food Chem., 2009, 114, pp. 1438 - 1443.

33. Noviyanto A., Abdulla, W.H. Honey botanical origin classification using hyperspectral imaging and machine learning. In: Journal of Food Engineering, 265, 2020, 109684. 
Disponibil: https://doi.org/10.1016/j.jfoodeng.2019.109684.

34. Puścion-Jakubik, A., Borawska, M.H., Socha, K. Modern Methods for Assessing the Quality of Bee Honey and Botanical Origin Identification. In: Foods , 2020, 9, pp.1028.

Disponibil: https://doi.org/10.3390/foods 9081028

35. Machado A.M., Miguel M.G., Vilas-Boas M., Figueiredo A.C. Honey Volatiles as a Fingerprint for Botanical Origin-A Review on their Occurrence on Monofloral Honeys. In: Molecules, 2020, 25, pp.374. Disponibil: https://doi.org/10.3390/molecules25020374

36. Boistean Alina, Chirsanova Aurica, Capcanari Tatiana, Siminiuc, Rodica. Evaluation of the color as a characterization parameter of honey from Tunisia, Romania and Moldova. In: Biotehnologii moderne - soluții pentru provocările lumii contemporane. 20-21 mai 2021, Chişinău. Chișinău, Republica Moldova: Tipografia "Artpoligraf", 2021, p. 43. ISBN 978-9975-3498-7-1

Disponibil: https://imb.md/sites/default/files/2021-

06/Simpozion\%20IMB2021\%20Publica\%C8\%9Bii_compressed.pdf .

37. Chen C. Relationship between Water Activity and Moisture Content in Floral Honey. In: Foods, 2019, 8 , pp. 30. Disponibil: https://doi.org/10.3390/foods 8010030

38. Omczyk M., Tarapatskyy M., Dżugan M. The influence of geographical origin on honey composition studied by Polish and Slovak honeys. In: Czech J. Food Sci., 2019, 37, pp. 232 - 238.

39. Maione R., Barbosa R., Barbosa R.M. Predicting the botanical and geographical origin of honey with multivariate data analysis and machine learning techniques: A review. In: Computers and Electronics in Agriculture, 2019, 157, pp.436-446. https://doi.org/10.1016/j.compag.2019.01.020.

40. Matzen, R.D., Leth-Espensen, J.Z., Jansson, T., Nielsen, D.S., Lund, M.N., Matzen, S. "The Antibacterial Effect In Vitro of Honey Derived from Various Danish Flora", Dermatology Research and Practice, vol. 2018, Article ID 7021713, 10 pages, 2018.

Disponibil: https://doi.org/10.1155/2018/7021713

41. Boussaid A., Chouaibi M., Rezig L., Hellal R., Donsì F., Ferrari G., Hamdi S. Physicochemical and bioactive properties of six honey samples from various floral origins from Tunisia, In: Arabian Journal of Chemistry, 11(2), 2018, pp. 265 - 274.

Disponibil: https://doi.org/10.1016/j.arabjc.2014.08.011.

42. Shapla U.M., Solayman M., Alam N. 5-Hydroxymethylfurfural (HMF) levels in honey and other food products: effects on bees and human health. In: Chemistry Central Journal, 2018,12(35). Disponibil: https://doi.org/10.1186/s13065-018-0408-3

43. Pasias I.N., Kiriakou I.K., Kaitatzis A., Koutelidakis A.E., Proestos C. Effect of late harvest and floral origin on honey antibacterial properties and quality parameters,Food Chemistry, 2018, 242, pp. 513 - 518.

Disponibil: https://doi.org/10.1016/j.foodchem.2017.09.083.

44. Council Directive of the European Union. Council directive 2001/110/ec of 20 december 2001 relating to honey. Off. J. Eur. Communities 2002, pp. 47 - 52.

Disponibil: https://eur-lex.europa.eu/legal-content/EN/ALL/?uri=CELEX:32001L0110

45. She S., Chen L., Song H., Lin G., Li Y., Zhou J., Liu C. Discrimination of geographical origins of Chinese acacia honey using complex 13C/12C, oligosaccharides and polyphenols. In: Food Chemistry, 2019, 272, pp. 580 - 585. Disponibil: https://doi.org/10.1016/j.foodchem.2018.07.227

46.Szabó R.T., Mézes M., Szalai T., Zajácz E., Kovács-Weber M. Colour identification of honey and methodical development of its instrumental measuring. In: Columella J. Agric. Environ. Sci., 2016, 3, pp. 29 - 36.

47. Vela L., De Lorenzo C., Pérez R.A. Antioxidant capacity of Spanish honeys and its correlation with polyphenol content and other physicochemical properties. In: J. Sci. Food Agric. 2007, 87, pp. 1069 - 1075.

48. Combarros-Fuertes P., Valencia-Barrera R.M., Estevinho L.M., Dias L.G., Castro J.M., Tornadijo M.E., Fresno, J.M. Spanish honeys with quality brand: A multivariate approach to physicochemical parameters, microbiological quality, and floral origin. In: J. Apic. Res., 2019, 58, pp. 92 - 103.

49. Ciappini M.C., Gatti M.B., Di Vito M.V. El color como indicador del contenido de flavonoides en miel. In: Rev. Cienc. Tecnol. 2013, 19, pp. 53 - 63.

50. De Silva P.M., Gauche C., Gonzaga L.V., Costa A.C.O. Honey: Chemical composition, stability and authenticity. In: Food Chem., 2016, 196, pp. 309 - 323. 